\title{
Implementation of the Physical Education, Sport and Health Learning Process Based on the 2013 Curriculum in Junior High Schools of Pariaman
}

\author{
Nurul Layla Fitri*, Rosmawati, Hendri Neldi \\ Faculty of Sport Science \\ Universitas Negeri Padang \\ Padang, Indonesia \\ nurulfitrilayla1996@gmail.com, \\ rosmawati-us@yahoo.co.id
}

\begin{abstract}
This study aims to find out or get information about learning planning, implementation of learning, and evaluation of learning in physical education, sports, and health in junior high schools of Pariaman City. This research is qualitative. The population of this research is the physical education, sports, and health teachers in junior high schools of Pariaman city registered academic year 2017/2018 that implement curriculum 2013 amounted to nine teachers. The sampling technique of this research is total sampling. The instruments used for obtaining data were documentation and observation, observing the teacher while doing the learning. Based on the results of the research conducted can be summed up some things as follows. First, the planning stage of learning by the teachers to the Learning Implementation Plan (RPP) is implemented every month is relatively good. Second, the implementation phase of learning conducted by teachers can be said well. Third, the Learning Evaluation Stage conducted by the teachers is appropriate with an assessment based on curriculum 2013 that is teacher use authentic assessment.
\end{abstract}

Keywords - implementation, learning, curriculum 2013

\section{INTRODUCTION}

Sports Physical Education and Health Education (PJOK) is part of the whole subject taught in school and cannot be separated from other education. The learning outcomes of Physical Sports Physical Education (PJOK) are expected to provide opportunities for students to be directly involved in processing learning activities through physical activities. Relating to the implementation of the current PJOK learning process, which has referred to the "2013 Curriculum"[1].

The learning process in the 2013 curriculum for all levels of education is carried out using a scientific approach (scientific approach). In the learning process based on scientific approaches, the realm of attitudes, skills, and knowledge. Within the scope of the 2013 curriculum in the physical and sports physical education learning process there is a learning planning, implementation of learning and evaluation of learning Mangamati transform substance or teaching material so that students about "why, how, what" the end result is the improvement and balance between the ability to become human beings good (soft skills), and people who have the skills and knowledge to live properly (hard skills) from students which include aspects of competence, attitudes, skills and knowledge. The 2013 curriculum emphasizes the modern pedagogic dimension in learning that is using a scientific approach.

"The physical and physical education learning process can be influenced by the development of students who are not the same, in addition to other characteristics inherent in students, such as; background aspects include the sex of the student, the place of birth and residence of the student, the socioeconomic level of the student, the family from which the student belongs and so forth"[2]. Based on the writer's observation, during the implementation of PJOK learning teachers in state junior high schools in Kota Pariaman the authors found irregularities in their learning activities, this is evident from the lack of active students in participating in the implementation of PJOK learning, as for the causes that the authors saw were student motivation to participate in learning, facilities and infrastructure learning, teacher unpreparedness in learning planning, implementation that still uses the old way and the lack of evaluation after learning.

As a result, the implementation of sports in the classroom and in the field seems to be just doing the obligation at the time of learning, the important thing is that the teacher has taught the teaching material and feedback from students is rarely evaluated by the teacher. The impact of all the implementation, it can be seen that the material given by the teacher in the classroom does not appear to be application in the field and students often show less active and creative attitude 
when practicing sports on the field.

PJOK subjects include group B subjects in the 2013 curriculum structure, namely groups of subjects whose content was developed by the center and supplemented with local wisdom content developed by the local government. The structure of this 2013 curriculum, PJOK subjects have content to contribute to developing movement competencies and healthy lifestyles, and to give color to the nation's character education. PJOK learning with local wisdom will give an appreciation of multiculturalism, which is about traditional games and sports that are rooted in the culture of Indonesian ethnic groups and can contribute to the formation of character [1].

"Concludes that learning planning is a process of decision making as a result of thinking rationally about specific learning goals and objectives, namely changes in behavior and the range of activities that must be carried out as an effort to deliver these goals by utilizing all the potentials and learning resources available"[3]

\section{RESEARCH METHODOLOGY}

This study uses a qualitative approach with descriptive methods and this research was carried out in SMP Negeri Pariaman City. The population of this study were PJOK teachers who teaches at SMP Negeri Kota Pariaman which consists of 9 schools totaling 17 teachers, with a sample collection of 9 teachers teaching in class VII and using the 2013 curriculum. Types of data in this study are primary data and secondary data and data sources in This research is a PJOK teacher in all state junior high schools in the City of Pariaman.

The instrument used in this study was in the form of observation and documentation. Data collection techniques in this study were: 1) Making a research permit, 2) Requesting data for PJOK teachers who teach in state junior high schools in Kota Pariaman to the Education Office, 3) Distributing permits research into copies of licensing letters, and 4) Visiting schools in the City of Pariaman to make observations. Data analysis techniques use Miles and Huberman's theory with three components namely data reduction, data presentation, and drawing conclusions or verification

\section{RESEARCH RESULTS AND DISCUSSION}

\section{A. Planning}

Planning can be a reference or guideline in carrying out learning activities and how learning assessment techniques will be carried out. Planning is not merely to fulfill administrative requirements as an educator. But it is part of the professional work process, so that it serves as a clear direction and guidance in implementing learning activities to achieve educational goals. The learning plans prepared by the teacher are listed in the Learning Implementation Plan (RPP).

RPP is one component that must be present in the implementation of learning. A teacher is required to make plans in the form of learning tools before teaching in class. Basic (KD) contained in the syllabus. In the syllabus not only study KI and KD only but also includes learning material, learning process, time allocation, and learning resources. Furthermore the teacher develops and designs the implementation of learning or makes lesson plans.

Based on the research results the teacher has made RPP for one semester, so the teacher does not make RPP every day. In addition, the results of the study also show that the eyes of PJOK junior high school teachers in Pariaman City have arranged a very good learning plan. This can be seen from the achievement of the indicators on observation instrument Learning Implementation Plan (RPP)

\section{B. Implementation}

"The implementation of learning is the interaction of teachers with students in order to deliver learning materials to students to achieve learning objectives. One aspect that influences the success of learning is the ability of teachers to manage learning"[5]. In learning this curriculum there are characteristics that are characteristic of the differentiator with the curriculum that has been there is namely the learning approach (scientific approach)

"The scientific approach in this activity includes the activities of observing, asking, collecting, information / trying, associating / reasoning, and communicating. Learning with a scientific approach is centered on students, while the teacher is only as a facilitator and one of the sources for the students"[4].

The results obtained from the implementation of learning show that PJOK subject teachers in Pariaman City State Junior High Schools have implemented PJOK learning according to the 2013 curriculum well. The data can be selected from the achievement of the indicators on the observation instrument which includes three stages of learning procedures, namely the preliminary, core, and closing activities.

PJOK subject teachers in Pariaman City Public Middle Schools with a scientific approach. The activities carried out by the teacher in learning are training and guiding students to think critically and creatively in solving problems, submitting ideas openly and freely. In this study the teacher has facilitated students to observe, ask questions, gather information / try, associate / reason, and communicating in learning activities.

Preliminary activities in learning function to create an effective start of learning that allows students to be able to follow the learning process properly. In the preliminary activities the steps taken 1) condition a pleasant learning atmosphere 2) relate the previous material with the material being studied 3) convey an outline of the scope of the material 4) provide apperception to foster students' curiosity. However, from the results of observations conducted by researchers there are a number of aspects that are rare and almost absolutely not done in the preliminary activities namely conveying the benefits of learning material to be learned in daily life and linking the previous material to the material to be studied.

"The core activities in learning play an important role 
in achieving learning objectives and in shaping the ability of students who have been determined"'5]. In the core activities or implementation of learning, the teacher has implemented a scientific approach that is observing, asking questions, gathering information / trying, associating / reasoning, and communicating. The 2013 curriculum-based learning model varies greatly.

In delivering the material, the teacher has used spoken and written language clearly and easily understood by students. The teacher uses methods and media to actively involve students in participating in PJOK learning. In general the teacher is able to master and manage the class well. Interaction between students and teachers also looks very good.

Next is the closing activity, the activities carried out by the teacher in the closing activity are generally appropriate. In concluding the lesson the teacher presents specific information. Then the teacher lures students to ask questions and answers to draw conclusions from the material being studied, do reflection, provide feedback on the process and learning outcomes, deliver the lesson plan for the next meeting.

\section{Learning Evaluation Activity}

The evaluation conducted by the State PJOKSMP teachers in Pariaman City was prepared in accordance with the Information Commission and the KD which were determined in the RPP, Information Commission and the $\mathrm{KD}$ were obtained from the syllabus and curriculum in 2013. Some PJOK teachers who teach in the State Junior High Schools in the City of Pariaman all apply the three aspects of the assessment .

These assessment activities must be carried out because they have their respective functions and roles. For example, attitude assessment, the assessment is used to assess the daily lives of students to their environment, courtesy to elders and mutual respect for peers. Knowledge assessment functions to assess the extent of students in understand and absorb the material provided. As for the skills to function see students practice the material that has been taught.

At the beginning of the new school year, respondents always tell students the assessment criteria and the Minimum Mastery Criteria (KKM). This is useful to motivate students to work hard in each of their learning because they know the standard values they must meet. That way learning in State Junior High Schools in Pariaman City takes place seriously and with the enthusiasm of the students.

Finally, regarding the ability of PJOK teachers to do remedial. All respondents think that remedial activities are very important because remedial is not only to improve the value of unfinished students, the activity is also useful so that students better understand the material being taugh

\section{CONClusions AND SUGGESTIONS}

Based on the results of research in state junior high schools in Pariaman City, several conclusions can be obtained as follows: 1) Teachers have been able to plan PJOK learning activities in junior high schools in
Pariaman City. It can be seen in the planning stages that teachers have prepared lesson plans, syllabus, mastered teaching materials and completed teaching materials. such as books, 2) Teachers have been able to carry out PJOK learning activities in SMPs in Pariaman City, this can be seen in the stages of classroom management, learning strategies and use of teaching media, 3) Teachers have been able to evaluate PJOK learning activities in SMPs in Pariaman City, this can be seen in the assessment stage using three aspects that have been determined; namely attitudes, knowledge and skills.

From the results of research on the implementation of 2013 curriculum-based PJOK learning, the authors suggest that: 1) school institutions are expected to be able to better complement the needs related to PJOK learning such as books, facilities and infrastructure, 2) teachers are expected to prepare a better learning implementation process. In terms of RPP preparation, use of learning methods and so on. So as to achieve maximum learning goals. In addition, PJOK teachers in Pariaman City Public Middle Schools are also expected to adjust their learning according to what is demanded by the 2013 curriculum, 3) educational institutions, it is hoped that this thesis can be used as additional reading material in the library that can be developed by parties in increasing the reader's insight to increasing knowledge about the performance of physical and health physical education teachers, 4) the next researcher is expected to be able to conduct research on the teaching and learning process of physical and health education based on the 2013 curriculum can be designed differently.

\section{REFERENCES}

[1] Kemendikbud, "Buku Guru Pendidikan Jasmani Olahraga dan Kesehatan,” Jakarta. 2017.

[2] Sanjaya, Wina, "Perencanaan dan Desain Sistem Pembelajaran," Jakarta; Kencana Prenada Media Group, 2008, PP. 78-90

[3] Syafruddin, Deswandi, and N,Ihsan, "Persepsi Siswa Terhadap Keterampilan Guru Dalam Pembelajaran Pendidikan Jasmani Olahraga dan Kesehatan di SDN 16 Pisang Kecamatan Pauh ota Padang," J. Menssana, [s.I.], v.3, n.1, p. 4866, Mei.2018.

[4] Menteri Pendidikan dan Kebudayaan Republik Indonesia, "Peraturan Menteri Pendidikan dan Kebudayaan no 81 a Tentang Implementasi Kurikulum, ” Jakarta, 2013.

[5] Fadillah, "Implementasi Kurukulum," Yogyakarta; Ar-rozz Media. 2013, pp, 48-68. . 